\title{
Between Reformist and Interpretation: Notes on Hamka's Methodological Strategies as Reformist Mufassir
}

\author{
Abdul Hanis Embong1,*, Wan Mohd. Khairul Firdaus Wan Khairuldin², Mohd. Faiz \\ Mohd. Yasin ${ }^{1}$, Azizul Hassan ${ }^{2}$, and Mohd. Sufi Ibrahim ${ }^{3}$
}

${ }^{1}$ Universiti Malaysia Terengganu (UMT), Terengganu, Malaysia

${ }^{2}$ Universiti Sultan Zainal Abidin (UNISZA), Terengganu, Malaysia

${ }^{3}$ Sofa Education Group (Yayasan Sofa), Kuala Lumpur, Malaysia

*Corresponding author email: hanis.embong@umt.edu.my

\begin{abstract}
Reformist mufassir is a suitable title to be given to Hamka, one of the Malay-Indonesian figures. He was a reformist of the Islamic revival in Indonesia and a mufassir to the Tafsir al-Azhar. However, is there any connection between the translation made and his reformist soul? What are the reformist elements in his translation to restore the greatness of the Muslim communities that have been left behind in every aspect and greatly influenced by the colonialists? Therefore, this paper of qualitative study, applied content analysis method towards Hamka's work, Tafsir al-Azhar, in order to answer these questions. The discussion in this paper was organized into two sections. First, a discussion on the background that influenced Hamka's reformist soul. Second, analyzing the reformist elements in Tafsir al-Azhar. As a result, this paper found five reformist patterns in the translation, namely the encouragement to use the senses and to think, the integration between the arguments of naqli and aqli, answering the accusations from Muslim enemies, answering the issues in Islamic society, and comparisons between the Torah, the Bible and the Qur'an. It can be concluded that all these reformist elements are essential of restoring the greatness of the Islamic generation, especially in Indonesia. These elements provide a new dimension in the discipline of tafsir and invite the community to change from the narrow-mindedness to the vast space of ijtihad.
\end{abstract}

Keywords: Hamka, Mufassir, Interpretation, Reformist, Tafsir al-Azhar

\section{INTRODUCTION}

Prof. Dr. Haji Abdul Malik Karim Amrullah or better known as Hamka is a prolific Islamic scholar and was actively involved in various disciples of Islamic preaching. Hamka's broad knowledge disciplines are particularly prominent in the fields of Sufism, creed, morals, history, literature, philosophy, jurisprudence and Quranic interpretation. He has authored 118 books covering all of these areas including his great masterpiece, Tafsir alAzhar.
Besides being a great academician, he was also a reformist, a modernist and an activist who had brought in thought reforms to the Muslim community in Indonesia [1]-[2]. Rush [3] describes Hamka as an Islamic modernist who shaped the true Islamic movement; he is also associated with the progressive interpretation of religious doctrines in the spirit of promoting important values, taking into account past and present context, adhering to principles rather than focusing solely on the reading of literary texts. 
Meanwhile, reformist-mufassir is one of the titles given to Hamka. It is not a new term, but the dimensions given to the field of interpretation are very impactful and influential. The researcher uses the term "reformistmufassir" as he finds that Hamka's work in writing interpretation was influenced by the reformist soul within him and this could actually be used as a tool to revive the thinking of the Muslim community in the Malay world back then that was underdeveloped and static (rigid) from the global development. This paper critically examines Hamka's life which was influenced by the reformist elements, and then extracts the reformist elements found in his interpretation to be used in the future.

\section{LITERATURE REVIEW}

Before going into the details of Hamka's role as a Muslim reformist-mufassir in Indonesia, this paper highlights on several studies related to Tafsir al-Azhar from various aspects carried out by previous researchers to justify the importance of his work on Quranic interpretation. Those works included are by Moussay [4], Une grande figure de l'Islam indonésien: Buya Hamka, Steenbrink [5], Hamka and the Integration of the Islamic Ummah of Indonesia, Steenbrink [6], Qur'an Interpretations of Hamzah Fansuri (CA. 1600) and Hamka [7]-[13]: A Comparison, and Rush [3], Hamka's Great Story. A Master Writer's Vision of Islam for Modern Indonesia.

Meanwhile, previous studies specifically related to Tafsir al-Azhar have been done by researchers covering various aspects. Most of the researches were done on the scope of Hamka's thoughts or perspectives through his writings in his interpretation. Among them are M. Y. Yusuf [14], Mashitah Ibrahim [15], Yaacob dan Maslan [16], Khusni [17], W. S. W. Yusuf [18], Mazlan Ibrahim [19], and Embong [22]-[28].

Besides that, there are recent researchers who have studied Tafsir al-Azhar from the perspective of his struggle in Indonesia are W. S. W. Yusuf [18] and Mazlan Ibrahim [19]. The study by Mazlan Ibrahim [19] focused on the social description found in Tafsir al-Azhar. The results of the study showed that the interpretation had strongly urged the Muslim community to return to the Islamic era led by the Prophet Muhammad PBUH. Likewise, the examples given recall a lot on the stories of the Prophets and the people of old as a lesson.

Even though many studies have been conducted pertaining to Hamka's struggle, there are not as many studies done about his struggle directly related to his interpretation. Thus, this paper seeks to explore the reformist elements which can be directly found in
Hamka's interpretation. This is well worth studying since Hamka is a philosopher with a wealth of struggle and scientific thinking capable of restoring the success of Muslims in the archipelago.

\section{METHODOLOGY}

This paper used the qualitative document research design. The main data were taken from Tafsir al-Azhar of volume 1 to volume 5 , while secondary data was obtained from literary method in the form of papers, journals, archives, scholarly books and scientific studies such as the thesis or dissertation related to Hamka and his interpretation. The data collected were then analyzed using textual content analysis (mawdu'iy) before coming to a thematic or focused conclusion.

\section{THE BACKGROUND THAT FORMS HAMKA'S REFORMIST SOUL}

Hamka's motivation as a reformist had been influenced from his birth until his adulthood from several aspects which were his lineage, community and education as detailed in this section.

\subsection{Lineage}

The process of formation of Hamka as a reformist and mufassir began indirectly since he was a child. Looking at his lineage, Hamka came from a lineage of clerical leaders in Minangkabau. His grandfather, Sheikh Muhammad Amrullah was a devout and respected Naqshabandiyah follower who was believed to have keramat and was called a wali. He studied in Mecca for five years and was the head of religious schools, surau and tarikat teachers. His grandfather followed in the footsteps of his father, Tuanku Syeikh Pariaman and his uncle, Tuanku Syeikh Gubug Katur, who was a learned man in religious knowledge and contributed a lot to the people throughout his life. In addition, Sheikh Muhammad Amrullah was also a student in Mecca to Sheikh Zaini and Sheikh Muhammad Hasbullah, and even learned from younger people like Sheikh Ahmad Khatib and Sheikh Tahir Jalaludin [21].

Hamka's biological father, Abdul Karim bin Amrullah was born in 1879. He was the most prominent of all children. Like his grandfather, Hamka's father also received religious studies in several surau or pondok in the Minangkabau area, once studied in Mecca for 6 or 7 years [11]. 


\subsection{Sociological}

When Hamka was born, the Minangkabau district was beginning to reform in the religious, educational and intellectual fields. The reform was facilitated by four prominent figures Syeikh Tahir Jalaluddin, Syeikh Muhammad Jamil Jambek, Haji Abdullah Ahmad and Hamka's father himself, Dr. Haji Abdul Karim Amrullah. The reform movement, driven by these four figures, was inspired by the thought of Sheikh Muhammad Abduh published in al-Manar magazine. At the same time, the religious disputes between the Kaum Muda who fought for religious advancement and the Kaum Tua who remained adherent to the custom, had grown worse during his birth [22]. Hamka, who was born at the rising time of the Kaum Muda, was actively involved in religious, educational, social and political reforms that had matured him in the religious standpoint [10].

During adulthood, Hamka had witnessed various conflicts arising between Islam and the country which had intensified as the Dutch were occupying Indonesia. The colonial government vigorously monitored and controlled the movements of the Muslims at that time [5]. In later life in 1965, he was jailed and finally released on 21 July [17]. All the knowledge and sweet and bitter experiences were best used to produce a good interpretation of the Qur'an in line with the purposes of the Qur'anic verses (Abdul Hanis Embong, 2014). He considered the imprisonment event as a gift from Allah SWT for being able to take the time to understand the contents of the Qur'an and to write the interpretation in peace [9].

Starting from such social conditions, it had influenced Hamka's adult personal self-development from childhood to adulthood, becoming more mature over time, especially in making him an Islamic reformist who fought for true Islamic teachings. At a later stage, his thoughts became more mature and progressive through education and activities he had pursued throughout his life that shaped him into a mature reformist-mufassir.

\subsection{Education}

Hamka's education began under the supervision of his father from an early age, beginning with learning the Qur'an from his father until he was six years old. Her father, also known as Haji Rasul, played an important role in shaping his son's religious thought [2]. A year later, at the age of seven, he started off his formal education in a village school in Padang Panjang in 1917 [23]. Later he also began to study religion and Arabic. In addition, he also diligently listened to religious lectures and studies in the surau and mosques delivered by prominent scholars at that time [23]. In secondary school, Hamka entered the Sekolah Desa (Village School) in Guguk Melintang
Padang Panjang in 1921. In the evening, he studied religion at Sekolah Diniyah which was then known as Sekolah Arab (Arabic School), which was the Sekolah Diniyah founded by Zainuddin Labai el-Yunusy in 1890 [9].

At the age of 17, Hamka returned to his hometown in Minangkabau after he had done with his studies in Java. Armed with the knowledge that he had, he began to talk about Islam in depth and preached to the people of Minangkabau. Later then, Hamka left his hometown for the holy land of Mecca. He intended to further his studies in Arabic while performing the pilgrimage [24].

Hamka returned to Indonesia after almost a year in Mecca completing both formal and informal studies, including his Qur'anic study from scholars in Mecca. His ability began to be recognized as a pious man who would succeed his father, Sheikh Abdul Karim Amrullah. Gradually, he gained the trust of the public to deliver religious lectures and preach [8].

The education that Hamka received from religious or nonreligious aspect had made him master various fields of knowledge that enabled him to see events happening around him from different perspective and not just through traditional conservative thought. Consequently, he was able to perform Quranic interpretation through a reformist's point of view as being a reformist needs to have a balanced consideration between two extremities i.e. worldy and hereafter life.

\section{ANALYSIS ON THE REFORMIST ELEMENTS IN TAFSIR AL-AZHAR}

Having identified the bases for Hamka reformist and his interpretation writings, this section discusses Hamka's interpretation and analyzes the reformist elements contained in Tafsir al-Azhar. This is because the struggle in Hamka's life has its own distinctive pattern with that of other mufassir, the explanations of the interpretation are also closely related to his reference in the process of perfecting his interpretation. The justification of the descriptions of the verses and events used as examples is clearly based on the Qur'an and the authentic Islamic references.

\subsection{Encouragement of the Use of Senses and To Think}

Hamka personally rejects the taqlid (simply imitate without having any arguments over the subject), he encourages Muslims through a mature process of thinking which he calls 'guided intellect' and utilizes the best of the senses given by Allah SWT. Hamka was among those 
who uphold the tradition of rationality, which is arguing with reasonable grounds for justifying actions, doings and guidances based on sound and mature considerations. Therefore, the explanations in Tafsir al-Azhar are often accompanied by a reminder to think and use their intellectual accordingly. While interpreting the verses on fasting, upon reaching the end of the explanation, Hamka usually concludes the interpretation of the verses of the Qur'an with some of the lessons and conclusions contained in the two verses. Examples are as follows:

Consecutively, the two verses answer three questions about alcohol, gambling and consuming orphans' belonging, but all three are one of the main things, which is about wealth. Everything is answered with satisfactory answers, and executed with an order to think. Answer that the essence is faith. Because faith brings honesty. If faith exists, then the orphan is not considered as someone else. The final conclusion of the third question is, think carefully for the sake of survival in the world and the hereafter [9].

In educating people to think, Hamka states:

And we must first remember that humans are created by God different from other beings. Humans are given the ability to weigh the bad and the good, the harm and the benefits. All rational humans do not like evil, nor do they desire harm. Humans are always looking for the better truth and with better benefits. Human's mind is made in such a way that it develops differently, some are high and some are low. The basic is to use the mind as best as we can as it is a gift from Allah [9].

Hamka's encouragement to think is repeated many times in his interpretation. This also shows that he wants the Muslim community in Indonesia to think deeply on all matters related to the consequences, especially when it involves the struggle and practice of worship in daily life. In spite of that, in Hamka's view, rationality based on thinking with sanity also has limitations, especially when it comes to matters of faith and belief. In this case, the rationality must be guided by the revelation of Allah SWT, the Qur'an and the hadith, and then translated into good moral values and manners continuously in every situation.

\subsection{The Unity Between Naqli With Aqli Proofs, Religious Knowledge with Modern Knowledge}

In Hamka's interpretation, he uses the tafsir bi-al-ma'thur approach, which is based on the Qur'an, al-Sunnah, the Companions' views and Tabiin's views. In addition, he also uses the tafsir bi al-ra'y approach, which is the personal interpretation of the mufassir. Therefore, in the event of a scientific study by Western scholars on the interpretation of the verse, he also adds that in so that his explanations become comprehensive and convincing.

An example of an explanation involving recent studies and general knowledge can be seen in the explanation of verse 223, surah al-Baqarah on the advantages of breast milk over cow's milk:

A distinguished scholar named Dr. Paul Gyorgy states in his explanation: 'Human milk is for human babies, and cow's milk is for calves.' He said that this was due to the fact that the use of breast milk for adult children is becoming less popular. Even in newly developed countries, including Indonesia, the Philippines, Brazil, Costa Rica, Libya and others, about $80 \%$ to $90 \%$ of babies are breastfed for about ten months, has also begun to decline. In fact, in developed countries like the United States for example, there are only $12 \%$ to $25 \%$ of babies who receive breast milk from their own mothers [9].

In the text above, he cited the fact that Western scholar Dr Paul Gyorgy had put forward the benefits of breast milk over other milk. He also presented detailed research evidence conducted by Westerners or orientalists to justify the facts presented. The fact was, in fact, to justify everything that Allah SWT had advocated in surah alBaqarah which is the necessity of breastfeeding.

In this regard, Hamka accepted the study conducted by an orientalist to balance his interpretations. He emphasized that Muslims nowadays need to be open minded and not need to be narrow-minded that they rejected every word of the orientalists. If there is any good in the study done, there is nothing wrong for Muslims to make use of the benefits of the study.

\subsection{Answering False Accusations from Enemies of Islam}

While working on his interpretations, Hamka recaptured many false accusations and diversion attempts made by enemies of Islam, especially from the West and answered them based on the Qur'an. He made every effort to repudiate their arguments through scientific discussions in order to restore true Islamic understanding. Examples of false accusations against Islam include fasting, the enemies of Islam stated that fasting caused Muslims to starve and begin to commit crimes such as stealing. Examples are as follows:

They claimed that during the fasting month, the Muslims would spend more than the usual 
expenses of the other months and ended up stealing. Such reasons were not scholarly, they were merely hatred. A thief was not a fasting person. Thieves were the ones who had corrupted hearts and souls. Accusing Muslims of being a thief because they fast are similar to accusing European Christians of being afflicted by the illness suffered by the Prophet Lut followers, because Christianity itself teaches solitary life to priests. And Christians drink heavily on Christmas Day, because their religion promotes wine drinking [9].

In the example above, Dutch officials had claimed that fasting led to theft. They said Muslims' spending increased during the fasting month and that prompted them to steal. Such accusation, according to Hamka, was not based on knowledge, but it was a hatred towards Islam. He responded to the accusation using Qur'anic justification and said that Christianity was the religion that caused its followers to sin, not Islam.

All of the discussions and arguments for each issue were presented by Hamka in pages of discussion. This proves how he determined he was in defending the pure teachings of Islam by denying the accusations based on the Qur'anic verses and philosophy.

\subsection{Providing Answers to Recent Issues in the Muslim Community}

Hamka also included recent issues of the Muslim community in the explanation of the Qur'anic verses' interpretation. These issues either occurred in Indonesia or in other Muslim countries. Feener [25] describes Hamka's writings as largely aimed at defending Islam against the Western modern understandings and the growing Communist threat. For example, while elaborating the verse on the banning of alcohol in surah al-Baqarah verse 184, Hamka recounted the situation in Indonesia after the spread of alcohol and gambling. He stated:

But we also regret on how the colonial government tried to destroy the lives of Muslims under their occupation, so they would be intoxicated with drinks and misery for gambling, that it became a secret in many Indonesian colonies during the time that officials, sulthans in East Sumatra, regents in Java became poor due to intoxication, especially because of gambling. Even some kings were taught to use opium and drugs, brought to the palace by the Kontelir as a gift. After the time of independence, it became worse as there were many people who liked to drink, but researchers from abroad did not see it as a common disease, because religious strength was still present at that time [9].

Based on this statement, Hamka exposed the ill effects of alcohol and gambling brought on by the Dutch colonialists, that he described the drinking habit as a disease.

In another situation, Hamka saw that the Indonesian community had gone astray from the Qur'anic practice. $\mathrm{He}$ felt that the generation of the Qur'an could only be born when the fundamentals of the Qur'an were first instilled in people's lives, the basis of which was reading the Qur'an. Therefore, he emphasized the benefits of reading the Qur'an when interpreting Surah al-Tin:

It is also reported by Ibnu Abbas and lkrimah: "Whoever gathers the Qur'an will not be returned to the ardzalil 'umur. To the senile, Insya Allah!" With regard to this, this interpretation writer is experienced. 'Ammati (my father's sister), Uaik Tuo Aisha died at the age of 86 . Over the years before her death, she had been deaf, and could not hear what we were talking about. But since she was a young girl, she obeyed her father's teaching, Tuanku Shaikh Amrullah, which is to finish reciting the Qur'an completely. And if there was no time to, she memorized several surahs, such as Yaa-Siin, alWaqi'ah, al-Kahfi, al-Mulk and a few other surahs. And these are the surahs she always recited. Therefore, despite being old and deaf, she did not become senile [9].

His experience was a valuable lesson, one who practices the recitation of the Qur'an will not become senile or forgetful. He could have simply put in the hadith of the Prophet (PBUH) to emphasize on this, but he preferred to include practical experiences or examples that the reader would appreciate and confide in every single thing he wanted to convey.

\subsection{Comparison between the Torah, the Bible and the Qur'an}

When describing Quranic verses, Hamka used a comparative approach between the contents of the Torah, the Bible and the verses of the Qur'an. Such a comparative method can be found in the verse interpretation pertaining to divorce. In describing the verse, he mentioned the law of divorce in the Christian teaching. The comparison was aimed to expose Muslims to deviations that existed in other religions other than Islam, thus reiterating Western accusations that Islam has no guarantee of women's rights. The law of divorce in Christian teaching is as follows: 
Mark 10-11: 'Anyone who divorces his wife and marries another woman, commits adultery against her. And if she divorces her husband and marries another man, she commits adultery.' In Christianity, once married, a couple is not allowed to split up, no divorce is allowed, just have to bear with the bad and the good, it is a very ideal teaching, but it is difficult to do so, because human will always be human [9].

Based on this excerpt, Hamka had rewritten the law of divorce in Christianity. Divorce is forbidden in Christianity, so it is not possible for a married couple to get a divorce regardless of any situation. In the event of divorce, adultery will happen when the other divorced couple is married. Nevertheless, Hamka stressed that the law is a very utopian idea and will torture the person if he or she cannot bear the marriage. In other words, the law would violate a human's right. The above explanations and examples prove that Hamka has taken a thorough comparative religion approach in explaining Qur'anic verses. From these comparisons, it is possible to know in depth the truth of Islam brought by the Prophet Muhammad PBUH.

Through the comprehensive discussion above, the following Figure 1 was built. It pictures the developmental process of Hamka's personality as a reformist-mufassir through his backgrounds and translated as the reformist elements in his great work, Tafsir alAzhar.

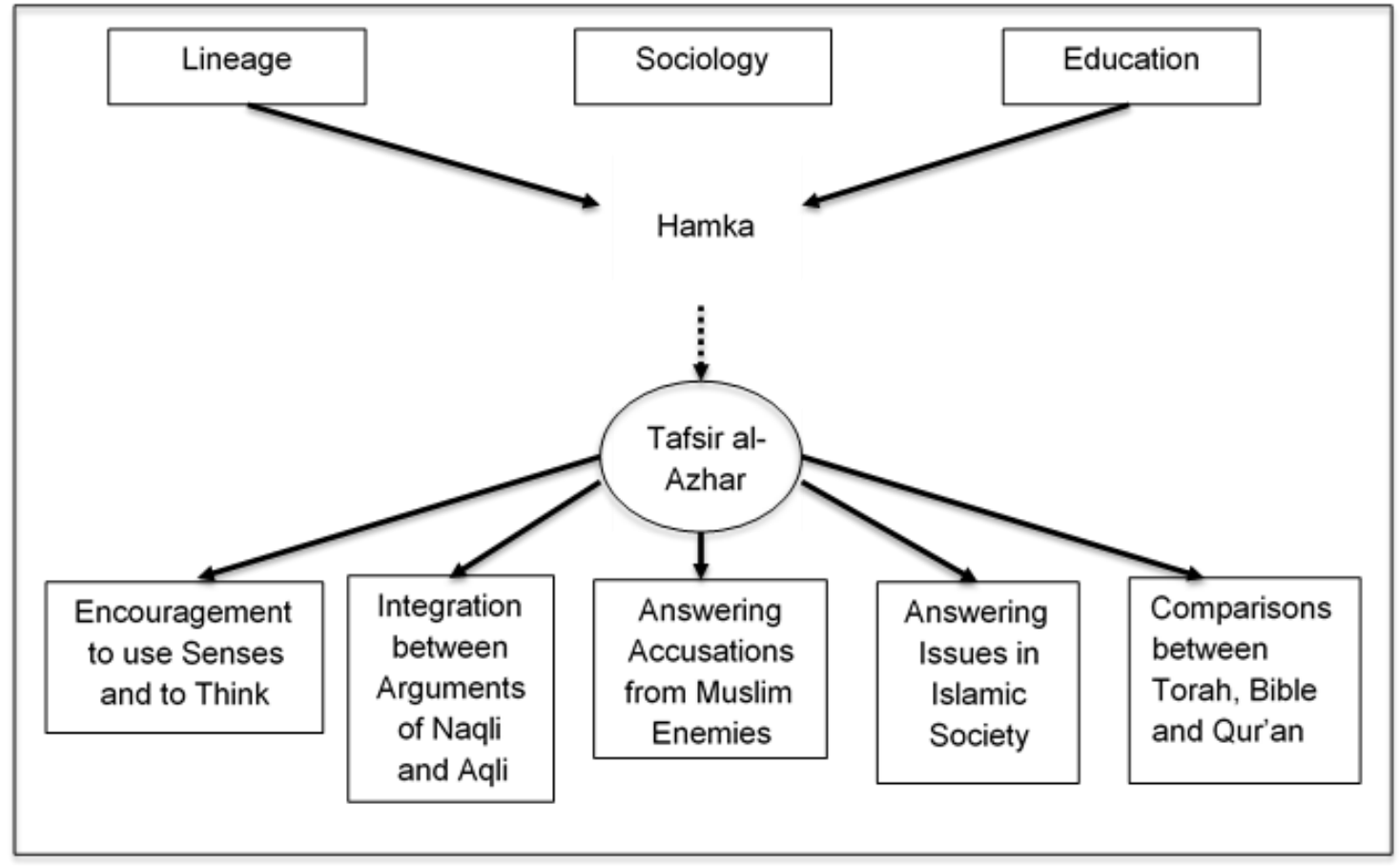

Figure 1 Development of Reformist Element in Tafsir al-Azhar

\section{CONCLUSION}

This paper proves that Hamka deserves the title of reformist-mufassir of Islam in Indonesia for incorporating reformist elements in the interpretation the best way possible. Through his interpretations, he vigorously defended Islam and rejected every slander created by the colonialists and improved the condition of the Muslim community. In his struggle with his interpretations, this paper has discovered five key elements of his description, namely the urge to use the senses and to think, the integration of the naqli and aqli arguments, religious and modern knowledge, the false accusations of the enemy of Islam, giving answers to recent issues in the Muslim community, comparisons between the Torah, the Bible and the Qur'an.

Clearly, Tafsir al-Azhar attempts to convey a new dimension to the world of interpretation through the reformist elements that Hamka incorporated into the description of Qur'anic verses. All five reformist elements found could be used by other mufassir in the quest to bring back the great Islamic generation. 


\section{ACKNOWLEDGMENT}

This article is supported by Knowledge and Technology Assimilation Grant Scheme (KTAGS) 2020, through project number UMT/PIJI/2-2/25/15/12-20 vot: 58906 . Thanks to University Malaysia Terengganu for the funding provided to undertake the study.

\section{REFERENCES}

[1] J. Pink, Tradition, Authority and Innovation in Contemporary Sunn̄̄ tafsīr: Towards a Typology of Qur'an Commentaries from the Arab World, Indonesia and Turkey. Journal of Qur'anic Studies, 12 (2010), 5682.

[2] N. Saat, Hamka's Great Story: A Master Writer's Vision of Islam for Modern Indonesia by James R. Rush (review). Sojourn: Journal of Social Issues in Southeast Asia, 32 (3) (2017), 754-756.

[3] J. R. Rush, Hamka's Great Story: A Master Writer's Vision of Islam for Modern Indonesia. Madison: The University of Wisconsin Press, 2016.

[4] G. Moussay, Une grande figure de l'Islam indonésien: Buya Hamka. Archipel, 32 (1986), 87-111.

[5] K. Steenbrink, Hamka (1908-1981) and The Integration of The Islamic Ummah of Indonesia. Studia Islamika Indonesian Journal for Islamic Studies, 1 (3) (1994), 119-147.

[6] K. Steenbrink, Qur'an Interpretations of Hamza Fansuri (CA. 1600) and Hamka (1908-1982): A Comparison. Studia Islamika Indonesian Journal for Islamic Studies, 2 (2) (1995), 73-95.

[7] Khairuldin, W. M. K. F. B. W., Embong, A. H., Hassan, S. A., Yasin, M. F. M., \& Anas, W. N. I. W. N. (2019). Strategic Management in Fatwa Making Process. Academy of Strategic Management Journal, 18(4), 1-6.

[8] Khairuldin, W. M. K. F. W., Anas, W. N. W. I. N., Embong, A. H., Hassan, S. A., Hanapi, M. S., \& Ismail, D. (2019). Ethics of Mufti in The Declaration of Fatwa According to Islam. Journal of Legal, Ethical and Regulatory Issues, 22(5), 1-6.
[9] Hamka, Pengantar Usul Fiqh, cetakan ke-3. Jakarta: Penerbit Djajamurni, 1966.

[10] Hamka, Ayahku. Jakarta: Penerbit Djajamurni, 1967.

[11] Hamka, Tafsir al-Azhar. Jakarta: Cetakan Pembimbing Masa, 1970.

[12] Hamka, Kenang-kenangan Hidup. Jil. 1-4. Jakarta: Bulan Bintang, 1974.

[13] Hamka, Doktrin Islam yang Menimbulkan Kemerdekaan dan Keberanian. Jakarta: Yayasan Idayu, 1982.

[14] Hamka, Hamka Membahas Soal-Soal Agama. Jakarta: Pustaka Panjimas, 1983.

[15] Hamka, Pelajaran Agama Islam. Jakarta: Bulan Bintang, 1984.

[16] M. Y. Yusuf, Corak Pemikiran Kalam Tafsir alAzhar: Sebuah Telaah Atas Pemikiran Hamka Dan Teologi Islam. Jakarta: Cetakan Penamadani, 2003.

[17] Mashitah Ibrahim, Metodologi Hamka di dalam Tafsir al-Azhar. Kuala Terengganu: Yayasan Islam Terengganu, 2001.

[18] N. H. Yaacob, A. Maslan, Pengaruh Pemikiran HAMKA (1908-1981) terhadap Perkembangan Wacana Sosio Keagamaan di Malaysia. Kertas Kerja Seminar Antarabangsa Agama dan Pembangunan MalaysiaIndonesia, Anjuran Fakulti Pengajian Islam, Universiti Kebangsaan Malaysia, Bangi, 3-4 Mei, (2010).

[19] A. Khusni, Konsep Ijtihad Hamka: Suatu Kajian Terhadap Masalah Fiqh Dalam Tafsir Al-Azhar. Tesis Sarjana, Universiti Kebangsaan Malaysia, 2006.

[20] W. S. W. Yusuf, Tafsir Al-Azhar: Cermin Perubahan Sosial Indonesia Abad ke-20 dalam Pemikiran dan Perjuangan HAMKA. Kuala Lumpur: Angkatan Belia Islam Malaysia, 2001.

[21] Mazlan Ibrahim, Tafsir Harian Al-Qur'an AlKarim. Kajian Tokoh Dan Metodologi Penulisan. 
Bangi: Fakulti Pengajian Islam, Universiti Kebangsaan Malaysia, 2008.

[22] A. H. Embong, Metodologi Tafsiran Ayat-Ayat Hukum Hamka dalam Tafsir al-Azhar. Disertasi Master, tidak diterbitkan. Bangi: Universiti Kebangsaan Malaysia, 2014.

[23] R. Hamka, Hamka Pujangga Islam Kebanggan Rumpun Melayu: Menatap Peribadi dan Martabatnya. Selangor: Terbitan Pustaka Dini, 2010.

[24] R. Hamka, Pribadi dan Martabat Buya Prof. Dr. Hamka. Jakarta: Pustaka Panjimas, 1983.

[25] R. Hamka, A. Hamka, Hamka Membahas SoalSoal Islam. Jakarta: Pustaka Panjimas, 1983.

[26] S. Salam, Kenang-Kenangan 70 Tahun Buya Hamka. Jakarta: Yayasan Nurul Islam, 1978.

[27] R. M. Feener, James R. Rush, Hamka's Great Story: A Master Writer's Vision of Islam for Modern Indonesia. The Journal of Religion, 97 (4) (2017) 583585.

[28] Yasin, M.F.B.M., Embong, A.H., Khairuldin, W.M.K.F.W., Said, S., Mutalib, N.A. (2018). Contributions of technology towards development of Qur'anic Tajweed knowledge. International Journal of Civil Engineering and Technology, 2018, 9(6), pp. 1340-1352 